\title{
PENGARUH BEBAN KERJA, KOMPETENSI SERTA KOMPENSASI TERHADAP PRESTASI KERJA KARYAWAN HOTEL EXCELTON PALEMBANG
}

\author{
Liliana $^{1}$, Muhni Pramuji ${ }^{2}$ \\ Universitas Tridinanti Palembang \\ Email : liliana.ishak@yahoo.com ${ }^{1}$, muhnipamuji@gmail.com²
}

\begin{abstract}
This study aims to determine the Effect of Workload, Competence and Compensation on Employee Performance at Excelton Hotel Palembang. The data used in this study are primary and secondary data, with data collection techniques carried out through questionnaire distribution to 68 employees of the Excelton Hotel Palembang. The analysis technique used is multiple linear analysis techniques that are processed using the help of the computer program Statistics Product and Service Soulution (SPSS 22). From the results of the study there is a positive and significant influence of Workload, Competence and Compensation on Employee Performance at the Excelton Hotel Palembang, which is indicated by the Regression model $=38.016+0.850 X 1+0.427 X 2+0.657 X 3+e$. Simultaneous correlation between the Work Load independent variable (X1), Competency independent variable (X2), Compensation independent variable (X3) to Work Performance dependent variable (Y) equals 0.724 means that there is a strong and positive directional relationship. Partial correlation of Workload (XI) to Work Achievement $(Y)$ equals 0.562 means that there is a fairly strong and positive relationship in the same direction, partial correlation of Competence (X2) to Work Achievement $(Y)$ equals 0.581 means that there is a strong enough relationship and positive direction, partial correlation Compensation (X3) to Job Performance $(Y)$ equals 0.613 means that there is a strong and positive directional relationship. This can be seen from the large coefficient of determination which is quite strong at $50.8 \%$ so there are still $49.8 \%$ of variables that cannot be examined. From the results of data conducted by researchers known Workload (X1), Competence (X2), Compensation (X3) significantly influence Work Performance $(Y)$ of Excelton Hotel Palembang Employees with a calculated $F$ value of 23,480 and a significant probability of $0.00<0$, 05. Workload (X1) has a significant effect on Work Performance (Y) with a calculated $T$ value of 3.496 and a significant probability of $0.001<0.05$. Competence (X2) has a significant effect on Job Performance $(Y)$ with a calculated $T$ value of 2.033 and a significant probability of $0.04<0.05$. Compensation (X3) has a significant effect on Job Performance (Y) with a calculated $T$ value of 2.776 and a significant probability of $0.007<0.05$.
\end{abstract}

Keywords: Workload, Competence, Compensation, Achievement. 


\section{PENDAHULUAN}

Berbagai upaya dapat dilakukan untuk meningkatkan prestasi maupun kinerja karyawan, antara lain dengan melakukan pelatihan, memberikan motivasi, pemberian kompensasi hingga penghargaan bagi karyawan yang berprestasi.

Selain itu, faktor beban kerja. Beban kerja merupakan sekumpulan atau sejumlah kegiatan yang harus diselesaikan oleh suatu unit perusahaan atau pemegang jabatan dalam jangka waktu tertentu. Saat menghadapi suatu masalah dan menyelesaikan tugas yang diberikan. Apabila keterbatasan yang dimiliki individu tersebut menghambat atau menghalangi tercapainya hasil kerja pada tingkat yang diharapkan, berarti telah terjadi kesenjangan antara tingkat kemampuan yang diharapkan dan tingkat kapasitas yang dimiliki karyawan. Semakin tingginya beban yang dirasakan para karyawan maka karyawan tersebut akan merasa bosan dan malas untuk bekerja sehingga prestasi kerja karyawan akan mengalami penurunan.

Suatu pekerjaan dapat memberikan resiko terhadap dampak yang dirasakan oleh pekerja, baik dalam jangka pendek atau jangka panjang.Hal tersebut sering disebut dengan beban kerja, yaitu dampak yang dirasakan karena aktivitas kerja yang dilakukan seharihari.Beban kerja berdampak secara langsung berdasarkan besarnya beban kerja yang dirasakan oleh pekerja Manuaba (2000).

Beban kerja yang diterima oleh pekerja harus sesuai dan seimbang dengan kemampuan fisik dan kemampuan kognitif maupun keterbatasan masing-masing pekerja dalam menerima beban tersebut Nurmianto (2004).

Maka jika pekerja yang merasakan beban kerja melebihi batas normal akan mengalami stres kerja pada fisik dan psikis. Seperti contohnya reaksi emosional, sakit kepala, dan gangguan pencernaan. Saat beban kerja yang dirasakan sedikit atau tidak terlalu berat akan mengakibatkan kebosanaan melakukan pekerjaan. Hal tersebut akan berdampak pada kurangnya motivasi untuk melakukan pekerjaan Manuaba (2000).

Dari pengertian diatas kompetensi individu merupakan sesuatu yang melekat dalam dirinya yang dapat digunakan untuk memprediksi tingkat prestasi kerja karyawan.Sesuatu yang dimaksud yaitu karakteristik kompetensi yang menyangkut motif, karakter pribadi, konsep diri, pengetahuan dan perilaku. Karakterisitik kompetensi tersebut dapat meramalkan suatu perilaku tertentu yang pada akhirnya akan muncul sebagai prestasi kerja.Keberhasilan suatu perusahaan sangat ditentukan oleh kualitas sumber daya manusia yang ada di dalamnya.Seiring dengan persaingan yang semakin kompetitif sebagai akibat dari perubahan selera pelanggan dan teknologi maka setiap perusahaan membutuhkan sumber daya manusia yang memiliki kompetensi yang baik, sehingga dapat dengan tanggap dalam menghadapi situasi tertentu dan dengan cepat mengambil suatu kebijakan.

Keberhasilan suatu perusahaan sangat ditentukan oleh kualitas sumber daya manusia yang ada di dalamnya. Seiring dengan persaingan yang semakin kompetitif sebagai akibat dari perubahan selera pelanggan dan teknologi maka setiap perusahaan membutuhkan sumber daya manusia yang memiliki kompetensi yang baik, sehingga dapat dengan tanggap dalam menghadapi situasi tertentu dan dengan cepat mengambil suatu kebijakan.

Kompetensi menentukan aspek-aspek proses kinerja pekerjaan. Suatu perusahaan dapat berjalan efektif dan efisien karena sumber daya manusia yang mendukung salah satu faktornya adalah kompetensi yang dapat menopang suatu kegiatan proses kinerja dengan tingkat keberhasilan suatu proses kerja yang tinggi maka prestasi kerja karyawan dapat dikatakan baik, yang akhirnya berimplikasi pada kinerja perusahaan. Dengan mengevaluasi kompetensi yang dimiliki oleh karyawan, dapat memprediksi kinerja karyawan tersebut. Karyawan yang ditempatkan pada tugas tertentu yang telah dinilai mengetahui kompetensi yang diperlukan.

Faktor lainnya yang mempengaruhi prestasi kerja yaitu kompensasi. Pemberian kompensasi yang baik dan adil juga akan mempengaruhi prestasi kerja karyawan. Karyawan akan banyak mengeluh apabila kompensasi yang diberikan tidak sesuai sehingga akan menyebabkan karyawan merasakan pekerjaanya tidak dihargai dan dampaknya terhadap penurunan prestasi kerja karyawan dikarenakan perusahaan tidak memberikan kompensasi yang sesuai dengan pekerjaan. Kompensasi diberikan dengan tujuan memberikan rangsangan untuk meningkatkan prestasi kerja, oleh karena itu bila kompensasi diberikan secara benar, maka 
karyawan akan lebih termotivasi untuk mencapai tujuan.

Selain faktor-faktor diatas, terdapat faktor lain yang mungkin berpengaruh terhadap prestasi kerja karyawan adalah budaya organisasi, kepemimpinan dan masih banyak lagi. Budaya organisasi dapat disimpulkan sebagai nilai-nilai yang menjadikan pegangan sumber daya manusia dalam menjalankan kewajiban dan perilakunya didalam organisasi sedangkan kepemimpinan merupakan kemampuan mempengaruhi orang lain, bawahan atau kelompok, kemampuan mengarahkan tingkah laku, memiliki kemampuan dalam bidang yang diinginkan oleh kelompoknya untuk mencapai tujuan organisasi. Pola kepemimpinan yang baik diharapkan mampu mengarahkan serta mengatur bawahan (karyawan) agar lebih termotivasi untuk lebih giat, lebih produktif serta dapat bekerja lebih efektif dan efisien sesuai dengan perintah kerja serta target yang harus dicapai perusahaan.

Hal tersebut terjadi juga di Hotel Excelton Palembang, dimana beban kerja karyawan masih dirasakan ada kesenjangan, dimana karyawan di level top manager, middle manager, beban kerjanya begitu sedikit tetapi memiliki gaji yang lebih besar dibandingkan staf karyawan yang memiliki beban kerja yang lebih besar dengan gaji hanya diukur berdasarkan Upah Minimum Regional (UMR). Hal ini berindikasi pada kinerja karyawan yang tidak optimal dalam memberikan pelayanan kepada tamu yang berkunjung atau menginap di hotel tersebut. Sering tidak tepat waktu dalam melakukan pelayanan kepada tamu hotel, mulai dari waktu tamu melakukan check in, saat tamu menginap hingga tamu check out.

Uraian di atas terjadi juga pada karyawan Hotel Excelton Palembang. Berdasarkan hasil observasi awal di hotel tersebut masih ditemukan adanya beberapa permasalahan klasik menyangkut prestasi kerja karyawan. Berbagai faktor yang menjadi pemicu utama adalah masalah kompensasi, selain faktor lainnya, seperti beban kerja dan kompetensi karyawan. Kompensasi yang diterima karyawan Hotel Excelton Palembang yang masih berbeda-beda tergantung pada jabatan dan lamanya bekerja. Diperkuat dengan hasil wawancara yang dilakukan dengan beberapa karyawan Hotel Excelton Palembangbahwa karyawan merasa gaji yang diterima sudah sesuai dengan Upah Minimum Regional
(UMR) Kota Palembang yaitu sebesar 2.678.000 untuk yang paling rendah, bonus yang diberikan belum sesuai dengan jam kerja serta jumlah tugas-tugas yang diberikan oleh pimpinan kepada karyawan kurang sepadan dengan gaji yang diterima dan minimnya fasilitas kerja yang tersedia di Hotel Excelton Palembang menjadi hambatan karyawan dalam melayani tamu hotel di Hotel Excelton Palembang.

Berdasarkan latar belakang yang telah diuraikan, maka penulis merasa tertarik untuk melakukan penelitian lebih lanjut dengan judul "Pengaruh Beban Kerja, Kompetensi dan Kompensasi Terhadap Prestasi Kerja Karyawan Hotel Excelton Palembang".

\section{METODOLOGI PENELITIAN}

\subsection{Kajian Teoritis}

Dalam penelitian ini terdapat 4 (empat) variabel yang akan diteliti, yaitu : variabel prestasi kerja sebagai variabel terikat, variabel beban kerja, kompetensi dan kompensasi sebagai variabel bebas. Dengan demikian, kerangka teori akan digambarkan mengenai 4 (empat) variabel tersebut dan indikatornya.

\subsection{Prestasi kerja}

Istilah prestasi kerja sering kita dengar atau sangat penting bagi sebuah organisasi untuk mencapai tujuannya. Dalam konteks pengembangan sumber daya manusia prestasi kerja seorang karyawan dalam sebuah organisasi sangat dibutuhkan untuk mencapai prestasi kerja bagi karyawan itu sendiri dan juga untuk keberhasilan organisasi tersebut. Prestasi kerja adalah hasil kerja seseorang karyawan selama periode tertentu dibandingkan dengan berbagai kemungkinan misalnya standard, target/sasaran atau kriteria yang telah ditentukan terlebih dahulu dan disepakati bersama.

Prestasi kerja merupakan hasil kerja seseorang karyawan selama periode tertentu dibandingkan dengan berbagai kemungkinan misalnya standard, target/sasaran atau kriteria yang telah ditentukan terlebih dahulu dan disepakati bersama.

Menurut Hasibuan (2008 : 64) menyatakan bahwa "Prestasi kerja adalah suatu hasil kerja yang dicapai seseorang dalam melaksanakan tugas-tugas yang dibebankan kepadanya yang didasarkan atas kecakapan, pengalaman, dan kesungguhan serta waktu. 
Selanjutnya Rivai (2004: 309) mengatakan bahwa Prestasi Kerja merupakan suatu fungsi dari motivasi dan kemampuan.

T. Hani Handoko (2007 :135), mengungkapkan sebagai berikut :

" prestasi kerja adalah suatu hasil kerja yang dicapai organisasi mengevaluasi dan menilai karyawan."

Berdasarkan beberapa pendapat di atas, dapat disimpulkan bahwa prestasi kerja adalah hasil kerja seseorang berdasarkan beban tanggung jawab yang diberikan kepadanya.prestasi kerja karyawan merupakan hasil yang dicapai karyawan dalam pelaksanaan suatu pekerjaan yang diberikan kepadanya baik secara kuantitas maupun kualitas melalui prosedur yang berfokus pada tujuan yang hendak dicapai serta dengan terpenuhinya standard pelaksanaan.

\subsection{Beban Kerja}

Secara umum beban kerja merupakan reaksi tubuh manusia ketika melakukan suatu pekerjaan eksternal.Mengingat kerjaan manusia bersifat mental dan fisik, maka masing-masing mempunyai tingkat pembebanan yang berbedabeda. Jika kemampuan pekerja lebih tinggi daripada tuntutan pekerjaan, akan muncul perasaan bosan dan overstress. Namun sebaliknya, jika pekerjaan lebih rendah daripada tuntutan pekerjaan maka akan muncul kelelahan yang lebih atau understress.

\subsection{Pengertian Beban Kerja}

Menurut Mudayana dalam Ahmad Hannani (2016:4) menyatakan "beban kerja merupakan sesuatu yang muncul dari interaksi antara tuntutan tugas-tugas, lingkungan kerja dimana digunakan sebagai teman kerja, keterampilan, perilaku, dan persepsi dari pekerja."

Menurut Siswanto dalam Nova Ellyzar (2017:38) menyatakan:

"Beban kerja adalah sejumlah kegiatan yang harus diselesaikan oleh suatu unit sorganisasi atau pemegang jabatan secara sistematis dengan menggunakan teknis analisis jabatan, teknik analisis beban kerja, atau teknik manajemen lainnya dalam jangka waktu tertentu untuk mendapatkan informasi tentang efisiensi dan efektivitas kerja suatu unit organisasi."
Menurut Munandar

(2014:20)

menyatakan "Beban kerja adalah tugas-tugas yang diberikan pada tenaga kerja atau karyawan untuk diselesaikan pada waktu tertentu dengan menggunakan keterampilan dan potensi dari tenaga kerja.

Berdasarkan beberapa definisi tersebut dapat disimpulkan bahwa beban kerja adalah sesuatu yang muncul yang dikarenakan jumlah kegiatan atau tugas-tugas yang harus diselesaikan oleh karyawan secara sistematis dengan menggunakan keterampilan yang harus diselesaikan berdasarkan waktu.

\subsection{Kompetensi}

Kompetensi merupakan kemampuan yang dimaksudkan sebagai kesanggupan karyawan untuk melaksanakan pekerjaan yang diberikan oleh pimpinan perusahaan.Kemampuan ini mengandung berbagai unsur kemampuan seperti kemampuan intelektual dan kemampuan manual bahkan sampai sifat-sifat pribadi yang dimiliki seorang karyawan. Berikut adalah beberapa pengertian kompetensi menurut beberapa ahli:

Menurut Michael Amstrong dalam Sedarmayanti (2015:235) menyatakan "Kompetensi adalah apa yang orang bawa pada suatu pekerjaan, dalam bentuk tipe dan tingkattingkat perilaku yang berbeda-beda."

Pendapat lain disampaikan oleh Lyle Spencer \& Signe Spencer dalam Sudarmanto (2015:46) menyatakan "Kompetensi merupakan karakteristik dasar perilaku individu yang berhubungan dengan kriteria acuan efektif dan atau kinerja unggul di dalam pekerjaan atau situasi.

$$
\begin{array}{clrr}
\text { Menurut } & \begin{array}{l}
\text { Margaret } \\
\text { Sedarmayanti }
\end{array} & \text { Dale dalam } \\
& (2015: 235) & \text { menyatakan }
\end{array}
$$
"Kompetensi adalah menggambarkan dasar pengetahuan dan standar kinerja yang dipersyaratkan agar berhasil menyelesaikan pekerjaan atau memegang suatu jabatan.

Berdasarkan beberapa definisi tersebut dapat disimpulkan bahwa kompetensi merupakan karkteristik individu yang menggambarkan pengetahuan dan standar kinerja dalam menyelesaikan pekerjaan yang diberikan oleh pimpinan. 


\subsection{Penelitian Terdahulu Yang Relevan}

Penelitian terdahulu yang relevan dengan penelitian yang akan penulis lakukan adalah penelitian dari Nurma Susilowati (2019), yang berjudul : " Pengaruh Beban Kerja, Kompetensi, dan Kompensasi Terhadap Prestasi kerja Karyawan Dengan Motivasi Sebagai Variabel Intervening PT. Bank Syariah Mandiri KCP Kartasura", yang narasinya sebagai berikut :

Penelitian ini bertujuan untuk menguji : (1) Pengaruh kompetensi terhadap prestasi kerja karyawan (2) Pengaruh kompensasi terhadap prestasi kerja karyawan (3) Pengaruh beban kerja terhadap prestasi kerja karyawan (4) Pengaruh motivasi kerja terhadap prestasi kerja karyawan (5) Pengaruh kompetensi terhadap prestasi kerja karyawan melalui motivasi kerja sebagai variabel intervening (6) Pengaruh kompensasi terhadap prestasi kerja karyawan melalui motivasi kerja sebagai variabel intervening (7) Pengaruh beban kerja terhadap prestasi kerja karyawan melalui motivasi kerja sebagai variabel intervening. Penelitian ini adalah penelitian kuntitatif menggunakan data primer, populasi dalam penelitian ini adalah seluruh karyawan BSM KCP Kartasura pada tahun 2018. Teknik pengambilan sampel dalam penelitian ini adalah sampel jenuh, yaitu teknik penentuan sampel bila semua anggota populasi digunakan sebagai sampel. Metode pengumpulan data dilakukan melalui kuesioner yang disebarkan kepada karyawan BSM KCP Kartasura pada tahun 2018. Data yang diperoleh kemudian diolah dengan menggunakan alat bantu SPSS versi 22. Analisis ini meliputi uji reliabilitas, uji validitas, uji statistik melalui uji-T, uji-F serta koefisien determinan (R2), uji asumsi klasik dan uji Path Analysis. Hasil uji-T menunjukkan bahwa secara parsial variabel kompensasi, kompensasi, beban kerja dan motivasi berpengaruh positif dan signifikan terhadap prestasi kerja karyawan. Dari hasil uji Path menunjukkan bahwa Kompetensi dan beban kerja berpengaruh positif dan signifikan terhadap prestasi kerja karyawan dengan motivasi kerja sebagai variabel intervening. Sedangkan kompensasi berpengaruh negatif tidak signifikan terhadap prestasi kerja karyawan dengan motivasi kerja sebagai variabel intervening.

Penelitian terdahulu yang relevan lainnya adalah penelitian dari Mahanto Prayuda (2014), yang berjudul : " Pengaruh Kompensasi dan
Beban kerja Terhadap Prestasi kerja Karyawan PT. Bank Tabungan Negara (Persero) Tbk, Kantor Wilayah D.I. Yogyakarta ", yang narasinya sebagai berikut :

Penelitian ini bertujuan untuk mengetahui: (1) pengaruh kompensasi terhadap prestasi kerja karyawan PT. Bank Tabungan Negara (Persero) Tbk, Kantor Wilayah Daerah Istimewa Yogyakarta, (2) pengaruh beban kerja terhadap prestasi kerja karyawan PT. Bank Tabungan Negara (Persero) Tbk, Kantor Wilayah Daerah Istimewa Yogyakarta, dan (3) pengaruh kompensasi dan beban kerja terhadap kinerja karyawan PT. Bank Tabungan Negara (Persero) Tbk, Kantor Wilayah Daerah Istimewa Yogyakarta. Penelitian ini menggunakan asosiatif kausal dengan pendekatan kuantitatif. Populasi dari penelitian ini adalah karyawan tetap di PT. Bank Tabungan Negara (Persero) Tbk, Kantor Wilayah Daerah Istimewa Yogyakarta adalah 98 karyawan. Data dikumpulkan dengan kuesioner yang telah diuji validitas dan reliabilitasnya. Teknik analisis data yang digunakan adalah regresi berganda. Hasil penelitian menunjukkan bahwa: (1) kompensasi berpengaruh positif dan signifikan terhadap prestasi kerja karyawan PT. Bank Tabungan Negara (Persero) Tbk, Kantor Wilayah Daerah Istimewa Yogyakarta, dibuktikan dengan koefisien beta sebesar $(\beta)$ sebesar 0,287; $\mathrm{p}=0,000$; dan kontribusi $(\Delta \mathrm{R} 2)$ sebesar $6,1 \%$; (2) beban kerja berpengaruh negatif dan signifikan terhadap prestasi kerja karyawan PT. Bank Tabungan Negara (Persero) Tbk, Kantor Wilayah Daerah Istimewa Yogyakarta, dibuktikan dengan koefisien beta $(\beta)$ sebesar 0,$285 ; \mathrm{p}=0,000$; dan kontribusi $(\Delta \mathrm{R} 2)$ sebesar 4,9\%; dan (3) kompensasi dan beban kerja berpengaruh signifikan secara simultan terhadap prestasi kerja karyawan PT. Bank Tabungan Negara (Persero) Tbk, Kantor Wilayah Daerah Istimewa Yogyakarta, dibuktikan dengan koefisien beta $(\beta)$ pada variabel kompensasi sebesar 0,229 dan $p=0,000$ dan koefisien beta $(\beta)$ pada variabel beban kerja sebesar $-0,205$ dan $\mathrm{p}=0,001$; dengan kontribusi sebesar $(\Delta \mathrm{R} 2)$ 8,4\%.

\subsection{Kerangka Pemikiran}

Kerangka berpikir dalam penelitian ini menggunakan kajian deskriptif, dengan kata lain bahwa kajian yang penulis terapkan menggunakan teori-teori yang dikemukakan para ahli. 
Dari pengertian dan hasil penelitian yang relevan dapat dijelaskan secara paradigma alur pikir sebagai berikut :

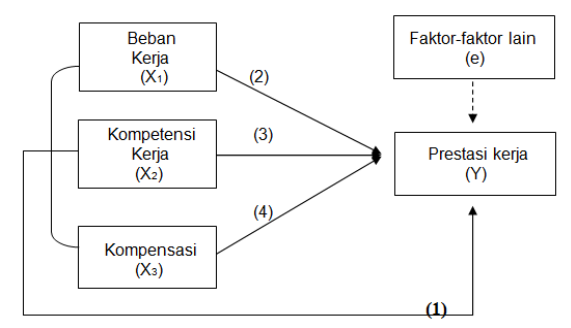

\subsection{Hipotesis Penelitian}

Peneliti dapat merumuskan hipotesis penelitian ini sebagai berikut :

1. Diduga beban kerja, kompetensi, dan kompensasi berpengaruh secara simultan terhadap prestasi kerja karyawan Hotel Excelton Palembang.

2. Diduga bahwa beban kerja berpengaruh secara parsial terhadap prestasi kerja karyawan Hotel Excelton Palembang.

3. Diduga kompetensi berpengaruh secara parsial terhadap prestasi kerja karyawan Hotel Excelton Palembang.

4. Diduga kompensasi berpengaruh secara parsial terhadap prestasi kerja karyawan Hotel Excelton Palembang.

\section{METODE PENELITIAN}

3.1 Tempat Penelitian

Penelitian dilaksanakan pada Hotel Excelton Palembang, dengan alamat jalan Demang Lebar Daun No.58c, Kecamatan Ilir Barat I, Kota Palembang.

\subsection{Populasi}

Populasi menurut Sugiyono (2013:148) adalah wilayah generalisasi yang terdiri atas: obyek/subyek yang mempunyai kualitas dan karakteristik tertentu yang ditetapkan oleh peneliti untuk dipelajari dan kemudian ditarik kesimpulannya. Dalam penelitian ini populasi yang dimaksud adalah seluruh karyawan Hotel Excelton Palembang dengan total kumulatif sebanyak 210 orang.

\section{Tabel 1}

\section{Data Karyawan Hotel Excelton Palembang}

\begin{tabular}{|l|c|c|c|}
\hline Jabatan / Unit & Jumlah & Sampel & Populasi \\
\hline $\begin{array}{l}\text { General } \\
\text { Manager }\end{array}$ & 2 & 2 & $\mathbf{2}$ \\
\hline
\end{tabular}

\begin{tabular}{|l|c|c|c|}
\hline $\begin{array}{l}\text { Executive } \\
\text { Secretary }\end{array}$ & 1 & 1 & $\mathbf{1}$ \\
\hline $\begin{array}{l}\text { Duty } \\
\text { Manager }\end{array}$ & 2 & 2 & $\mathbf{2}$ \\
\hline $\begin{array}{l}\text { F \& B } \\
\text { Manager }\end{array}$ & 2 & 2 & $\mathbf{2}$ \\
\hline $\begin{array}{l}\text { Front Office } \\
\text { Manager }\end{array}$ & 2 & 2 & $\mathbf{2}$ \\
\hline $\begin{array}{l}\text { Executive } \\
\text { Housekeep }\end{array}$ & 2 & 2 & $\mathbf{2}$ \\
\hline $\begin{array}{l}\text { Sales \& } \\
\text { Marketing }\end{array}$ & 5 & 5 & $\mathbf{5}$ \\
\hline $\begin{array}{l}\text { Chief } \\
\text { Engineer }\end{array}$ & 2 & 2 & $\mathbf{2}$ \\
\hline $\begin{array}{l}\text { Staf } \\
\text { Karyawan }\end{array}$ & 192 & 50 & $\mathbf{1 9 2}$ \\
\hline \multicolumn{1}{|l}{ Jumlah } & $\mathbf{2 1 0}$ & $\mathbf{6 8}$ & $\mathbf{2 1 0}$ \\
\hline
\end{tabular}

Sumber : Hotel Excelton Palembang, 2019

\subsection{Sampel}

Sampel merupakan suatu bagian dari populasi yang ingin diteliti oleh peneliti menurut Sugiono, (2013:149). Sampel adalah bagian dari jumlah populasi yang ada sehingga untuk pengambilan sampel harus menggunakan cara tertentu yang berdasarkan oleh pertimbangan-pertimbangan yang ada. Dalam penelitian ini metode yang digunakan untuk menentukan jumlah sampel adalah menggunakan rumus Slovin dengan menggunakan toleransi $10 \%$ yaitu sebagai berikut :

$$
n=\frac{N}{1+N(e)^{2}}
$$

Keterangan:

$\mathrm{n}=$ jumlah sampel

$\mathrm{N}=$ jumlah populasi

$\mathrm{E}=$ jumlah toleransi kesalahan (error tolerance)

Perhitungan :

$$
\begin{aligned}
& n=\frac{210}{1+210(0,10)^{2}} \\
& =\frac{210}{1+210(0,01)} \\
& =\frac{210}{3,1} \\
& =67,74=68
\end{aligned}
$$

Berdasarkan perhitungan dengan rumus Slovin maka jumlah sampel diperoleh sebanyak 68 orang dari total populasi sebanyak 210 orang. 


\subsection{Teknik Sampling}

Sampling adalah teknik untuk menentukan sampel penelitian dengan beberapa pertimbangan tertentu yang bertujuan agar dapat diperoleh nantinya bisa refresentatif, Sugiono (2014:152).

Teknik pengambilan sampel dalam penelitian ini adalah sampling probability (acak) dan sampling non probability (non acak). Sampling probability (acak) adalah teknik sampling yang memberikan peluang yang sama bagi setiap unsur atau anggota populasi untuk dipilih anggota sampel sedangkan sampling non probability (non acak) adalah teknik sampling yang tidak memberikan peluang atau kesempatan yang sama bagi setiap unsur atau anggota populasi untuk dipilih menjadi sampel. Dengan cara ini semua elemen populasi belum tentu memiliki peluang yang sama untuk dipilih menjadi anggota sampel. Cara ini juga sering disebut sebagai pengambilan sampel berdasarkan pertimbangan karena dalam pelaksanaannya digunakan pertimbangan tertentu.

\subsection{Definisi Operasional Variabel}

Definisi operasional yang digunakan dalam penelitian ini kemudian diuraikan menjadi indikator empiris yang meliputi:

\section{A. Prestasi kerja karyawan}

Menurut Sutrisno (2010:152), mengatakan pengukuran prestasi kerja diarahkan pada enam aspek yang merupakan bidang prestasi kunci bagi organisasi yaitu :

1. Hasil kerja, yang meliputi:
a) Kuantitas pekerjaan diselesaikan batas waktu yang ditentukan
b) Belajar sesuai prosedur yang ditetapkan
c) Jarang membuat kesalahan dalam bekerja

2. Pengetahuan kerja, yang meliputi:

a) Menguasai prosedur kerja; dan

b) Memiliki pengetahuan umum serta konsep tentang pelaksanaan pekerjaan

3. Inisiatif yang meliputi:
a) Tanggap terhadap pekerjaan
b) Mampu memecahkan masalah

4. Kecekatan yang meliputi :
a) Cepat menerima instruksi kerja

b) Mampu menyesuaikan diri
5. Sikap yang meliputi :

a) Semangat dalam bekerja

b) Mampu bersikap positif

6. Disiplin waktu dan Absensi yang meliputi :
a) Hadir tepat waktu
b) Menerima konsekuensi atas ketidakhadiran

\section{B. Beban kerja}

Menurut Munandari (2014), beban kerja adalah tugas-tugas yang diberikan pada tenaga kerja atau karyawan untuk diselesaikan pada waktu tertentu dengan menggunakan keterampilan dan potensi dari tenaga kerja.

Beban kerja terdiri dari 3 (tiga) dimensi,yaitu :

Beban Fisik, yaitu : beban fisik
fisiologis dan beban fisik
biomekanika.
2) Beban Mental, yaitu : konsentrasi, adanya rasa bingung, kewasapadaan dan ketepatan pelayanan.

3) Beban Waktu, yaitu: kecepatan dalam mengerjakan pekerjaan dan mengerjakan pekerjaan dua/lebih dalam waktu yang sama.

\section{Kompetensi}

Kompetensi merupakan karakteristik dasar perilaku individu yang berhubungan dengan kriteria acuan efektif dan atau kinerja unggul di dalam pekerjaan atau situasi.

Menurut Sudarmanto (2015), ada 3 (tiga) dimensi kompetensi yaitu :

1) Sikap (Attitude), indikatornya yaitu : Motiv, watak dan konsep diri

2) Pengetahuan (Knowledge), indikatornya yaitu :pendidikan, pengetahuan yang dimilik mendukung pekerjaan dan pengetahuan dalam mengidentifikasi masalah.

3) Kemampuan (Skill), indikatornya yaitu :kemampuan melayani tamu, kemampuan berkomunikasi dan kemampuan beradaptasi terhadap perubahan.

\section{Kompensasi}

Menurut Sedarmayanti (2015), kompensasi merupakan segala sesuatu yang diterima oleh karyawan sebagai balas jasa atau kontribusinya kepada 
perusahaan/organisasi. Kompensasi terdiri dari 2 (dua) dimensi yaitu :

- Kompensasi langsung, indikator kompensasi langsung yaitu: kesesuaian gaji dengan pekerjaan, kesesuaian insentif dengan hasil yang diterima dan bonus yang dterima sesuai dengan pekerjaan

- Kompensasi tidak langsung, indikator dari kompensasi tidak langsung yaitu: kesesuaian pemberian tunjangan dengan yang diharapkan, kesesuaian asuransi dengan kebutuhan hidup, kesesuaian fasilitas dengan kebutuhan pekerjaan dan kesesuaian penghargaan yang diberikan dengan hasil kerja

\subsection{Analisis Data}

\section{Regresi Linier Berganda}

Analisis ini digunakan untuk mengetahui seberapa besar pengaruh variabel bebas yaitu: beban kerja $\left(\mathrm{X}_{1}\right)$, kompetensi $\left(\mathrm{X}_{2}\right)$, dan kompensasi $\left(\mathrm{X}_{3}\right)$ terhadap variabel terikatnya yaitu prestasi kerja karyawan (Y).

Persamaan regresi linier berganda adalah sebagai berikut Ghozali (2015):

Dimana:

$$
\mathbf{Y}=\mathbf{a}+\mathbf{b}_{1} \mathbf{X}_{1}+\mathbf{b}_{2} \mathbf{X}_{2}+\mathbf{b}_{3} \mathbf{X}_{3}+\mathbf{e}
$$

$\mathrm{Y}=$ Variabel dependen (prestasi kerja karyawan)

a $=$ Konstanta

$\mathrm{b}_{1}, \mathrm{~b}_{2}, \mathrm{~b}_{3}=$ Koefisien garis regresi

$\mathrm{X}_{1}, \mathrm{X}_{2}, \mathrm{X}_{3}=$ Variabel independen (beban kerja, kompetensi, kompensasi)

$$
\mathrm{e} \quad=\text { error/ variabel pengganggu }
$$

\section{Analisis Korelasi}

Analisis korelasi adalah metode statistika yang digunakan untuk menentukan kuatnya atau derajat hubungan linier antara dua variabel atau lebih. Semakin nyata hubungan linier (garis lurus), maka semakin kuat atau tinggi derajat hubungan garis lurus antara kedua variabel atau lebih. Ukuran untuk derajat hubungan garis lurus ini dinamakan koefisien korelasi.

Korelasi dilambangkan dengan $r$ dengan ketentuan nilai $r$ tidak lebih dari harga $(-1 \leq r \leq 1)$. Apabila nilai $r=-1$ artinya korelasi negatif sempurna; $r=0$ artinya tidak ada korelasi; dan $\mathrm{r}=1$ artinya korelasinya sangat kuat.
Tabel 2

Interpretasi Koefisien Korelasi Nilai $\mathbf{r}$

\begin{tabular}{|c|c|}
\hline Interval Koefisien & Tingkat Hubungan \\
\hline $0,800-1,000$ & Sangat Kuat \\
\hline $0,600-0,799$ & Kuat \\
\hline $0,400-0,599$ & Cukup Kuat \\
\hline $0,200-0,399$ & Lemah \\
\hline $0,000-0,199$ & Sangat Lemah \\
\hline
\end{tabular}

Analisis korelasi berganda berfungsi untuk mencari besarnya hubungan antara dua variabel bebas $(\mathrm{X})$ atau lebih secara simultan dengan variabel terikat (Y). Rumus korelasi berganda adalah sebagai berikut :

\section{Analisis Diterminasi}

Koefisien determinasi digunakan untuk mengukur seberapa besar kemampuan model dalam menerangkan variabel terikat. Jika R2 semakin besar (mendekati 1), maka dapat dikatakan bahwa pengaruh variabel bebas (X) adalah besar terhadap variabel terikat (Y). Hal ini berati model yang digunakan semakin kuat untuk menerangkan pengaruh variabel bebas yang teliti terhadap variabel terikat.

Sebaliknya jika R2 semakin mengecil (mendekati 0) maka dapat dikatakan bahwa pengaruh variabel bebas $(\mathrm{X})$ terhadap variabel terikat (Y) semakin kecil. Hal ini berarti model yang digunakan tidak kuat untuk menerangkan variabel bebas yang teliti terhadap variabel terikat.

Pengujian Hipotesis dalam penelitian ini dilakukan dengan melihat hasil statistik regresi, yaitu pengujian yang dilakukan untuk melihat apakah variabel independen mempunyai pengaruh yang signifikan terhadap variabel dependen.

\subsection{Pengujian Hipotesis}

\section{Uji Signifikansi Simultan (Uji Statistik F)}

Dalam penelitian ini, uji $F$ digunakan untuk mengetahui tingkat siginifikansi pengaruh variabel-variabel independen secara bersama-sama (simultan) terhadap variabel dependen Ghozali (2015). Dalam penelitianini, hipotesis yang digunakan adalah:

Ho : Variabel-variabel bebas yaitu beban kerja, kompetensi dan kompensasi tidak mempunyai pengaruh yang signifikan secara bersama-sama terhadap variabel terikatnya yaitu prestasi kerja karyawan 
Ha : Variabel-variabel bebas yaitu beban kerja, kompetensi dan kompensasi mempunyai pengaruh yang signifikan secara bersama-sama terhadap variabel terikatnya yaitu prestasi kerja karyawan.

Langkah-langkah sebagai berikut :

a. Merumuskan Hipotesis

Ho, b1, b2, b3 = 0, tidak ada pengaruh beban kerja, kompetensi dan kompensasi terhadap prestasi kerja karyawan.

Ho, b1, b2, b3 $\neq 0$, ada pengaruh beban kerja, kompetensi dan kompensasi terhadap prestasi kerja karyawan

b. Menentukan level of significant $\alpha=5 \%$

c. Kriteria Pengujian

$F_{\text {hitung }} \geq F_{\text {tabel, }}$, Ho diterima, Ha ditolak

$F_{\text {hitung }} \leq \mathrm{F}_{\text {tabel, }}$, Ho ditolak, Ha diterima

d. Kesimpulan

Jika $F_{\text {hitung }} \geq F_{\text {tabel}}$, Ho diterima, Ha ditolak Artinya tidak ada pengaruh beban kerja, kompetensi dan kompensasi terhadap prestasi kerja karyawan.

Jika $F_{\text {hitung }} \leq \mathrm{F}_{\text {tabel}}$, Ho ditolak, Ha diterima Artinya ada pengaruh beban kerja, kompetensi dan kompensasi terhadap prestasi kerja karyawan.

\section{Uji Signifikasi Parsial (Uji T)}

Uji $t$ digunakan untuk menguji signifikansi hubungan antara variabel $\mathrm{X}$ dan $\mathrm{Y}$, apakah variabel $\mathrm{X}_{1}, \mathrm{X}_{2}$, dan $\mathrm{X}_{3}$ (beban kerja, kompetensi dan kompensasi) benar-benar berpengaruh terhadap variabel Y (prestasi kerja karyawan) secara terpisah atau parsial Ghozali (2015).

Hipotesis yang digunakan dalam pengujian ini adalah:

Ho : Variabel-variabel bebas (beban kerja, kompetensi dan kompensasi) tidak mempunyai pengaruh yang signifikan

\begin{tabular}{|c|c|c|c|c|c|}
\hline \multicolumn{6}{|c|}{$\begin{array}{c}\text { Tabel 3 } \\
\text { Coefficients }^{\mathrm{a}}\end{array}$} \\
\hline \multirow[b]{2}{*}{ Model } & \multicolumn{2}{|c|}{$\begin{array}{l}\text { Unstandardized } \\
\text { Coefficients }\end{array}$} & \multirow{2}{*}{\begin{tabular}{|c|}
$\begin{array}{c}\text { Standardi } \\
\text { zed } \\
\text { Coefficie } \\
\text { nts }\end{array}$ \\
Beta \\
\end{tabular}} & \multirow[b]{2}{*}{$\mathrm{t}$} & \multirow[b]{2}{*}{ Sig. } \\
\hline & B & Std. Error & & & \\
\hline $\begin{array}{l}1 \text { (Const } \\
\text { ant) }\end{array}$ & $-38,016$ & 16,402 & & $-2,318$ & ,024 \\
\hline $\mathrm{x} 1$ & ,850 & ,243 & ,336 & 3,496 & ,001 \\
\hline$x 2$ & , 427 & ,210 & ,236 & 2,033 & 046 \\
\hline$x 3$ & ,657 & ,237 & ,323 & 2,776 & ,007 \\
\hline
\end{tabular}

terhadap variabel terikat (prestasi kerja karyawan).
Ha : Variabel-variabel bebas (beban kerja, kompetensi dan kompensasi) mempunyai pengaruh yang signifikan terhadap variabel terikat (prestasi kerja karyawan).

Langkah-langkah sebagai berikut :

a. Merumuskan Hipotesis

1) Pengaruh beban kerja secara parsial terhadap prestasi kerja karyawan

Ho ; b1 $=0$, tidak ada pengaruh beban kerja secara parsial terhadap prestasi kerja karyawan

Ho ; b1 $\neq 0$, ada pengaruh beban kerja secara parsial terhadap prestasi kerja karyawan

2) Pengaruh kompetensi secara parsial terhadap prestasi kerja karyawan

Ho ; b2 = 0, tidak ada pengaruh kompetensi secara parsial terhadap prestasi kerja karyawan

Ho ; b2 $\neq 0$, ada pengaruh kompetensi secara parsial terhadap prestasi kerja karyawan

3) Pengaruh kompensasi secara parsial terhadap prestasi kerja karyawan

Ho ; b3 $=0$, tidak ada pengaruh kompensasi secara parsial terhadap prestasi kerja karyawan

Ho ; $\mathrm{b} 3 \neq 0$, ada pengaruh kompensasi secara parsial terhadap prestasi kerja karyawan

b. Menentukan level of significant $\alpha=5 \%$

c. Kriteria Pengujian $t_{\text {hitung }} \geq t_{\text {tabel }}$, Ho diterima, Ha ditolak $t_{\text {hitung }} \leq t_{\text {tabel }}$, Ho ditolak, Ha diterima

d. Kesimpulan

Jika $t_{\text {hitung }} \geq t_{\text {tabel }}$, Ho diterima, Ha ditolak. Artinya tidak ada pengaruh beban kerja, kompetensi dan kompensasi terhadap prestasi kerja karyawan.

Jika $t_{\text {hitung }} \leq \mathrm{t}_{\text {tabel }}$, Ho ditolak, Ha diterima. Artinya ada pengaruh beban kerja, kompetensi dan kompensasi terhadap prestasi kerja karyawan.

\section{HASIL DAN PEMBAHASAN \\ 4.1 Analisis Data \\ Analisis Regresi Berganda}

Analisis ini digunakan untuk mengetahui hubungan antara dua atau lebih variabel Beban Kerja $\left(X_{1}\right)$, Kompetensi $\left(X_{2}\right)$, dan Kompensasi $\left(X_{3}\right)$ terhadap variabel Prestasi Kerja (Y) karyawan Hotel Excelton Palembang. Dari hasil perhitungan statistik yang menggunakan SPSS yang tertera pada label berikut : 


\section{Regresi Berganda}

Berdasarkan tabel koefisien (tabel 4.10) di atas, persamaan regresinya adalah sebagai berikut:

$$
\begin{aligned}
& Y=-38,016+0.850 \mathrm{X} 1+0,427 \mathrm{X} 2+0,657 \mathrm{X} 3 \\
& +\mathrm{e} \\
& \text { dengan } \hat{Y}=\text { variabel terikat Prestasi Kerja } \\
& \text { Karyawan } \\
& X_{1}=\text { variabel bebas Beban Kerja } \\
& X_{2}=\text { variabel bebas Kompetensi } \\
& X_{3}=\text { variabel bebas Kompensasi }
\end{aligned}
$$$$
\wedge
$$

Dari persamaan regresi di atas dapat dijelaskan sebagai berikut:

a. Jika variabel bebas Beban Kerja $\left(X_{1}\right)$, Kompetensi $\left(X_{2}\right)$, dan Kompensasi $\left(X_{3}\right)$ tidak ditingkatkan maka nilai variabel terikat Prestasi Kerja Karyawan (Y) akan bernilai sebesar -38,016.

b. Jika variabel bebas Beban Kerja $\left(X_{1}\right)$ mengalami peningkatan sebesar 1(satu) satuan unit skor, maka variabel terikat Prestasi Kerja Karyawan (Y) akan meningkat sebesar 0,850 .

c. Jika variabel bebas Kompetensi $\left(X_{2}\right)$ mengalami peningkatan sebesar 1(satu) satuan unit skor, maka variabel terikat Prestasi Kerja Karyawan (Y) akan meningkat sebesar 0,427.

d. Jika variabel bebas Kompensasi $\left(X_{3}\right)$ mengalami peningkatan sebesar 1(satu) satuan unit skor, maka variabel terikat Prestasi Kerja Karyawan (Y) akan meningkat sebesar 0,657.

\section{Analisi Korelasi}

\begin{tabular}{|c|c|c|c|c|c|}
\hline & $\begin{array}{l}\text { Sum of Squares } \\
\text { and Cross- } \\
\text { products } \\
\text { Covariance } \\
\mathrm{N}\end{array}$ & $\begin{array}{r}442,02 \\
9 \\
6,597 \\
68\end{array}$ & $\begin{array}{r}311,4 \\
71 \\
4,649 \\
68\end{array}$ & $\begin{array}{r}174,3 \\
53 \\
2,602 \\
68\end{array}$ & $\begin{array}{r}156,8 \\
24 \\
2,341 \\
68\end{array}$ \\
\hline \multirow[t]{5}{*}{$x 2$} & $\begin{array}{l}\text { Pearson } \\
\text { Correlation }\end{array}$ & & & 1 & \\
\hline & Sig. (2-tailed) & ,000 & ,001 & & ,000 \\
\hline & $\begin{array}{l}\text { Sum of Squares } \\
\text { and Cross- } \\
\text { products }\end{array}$ & $\begin{array}{r}638,64 \\
7\end{array}$ & $\begin{array}{r}174,3 \\
53\end{array}$ & $\begin{array}{r}607,7 \\
65\end{array}$ & $\begin{array}{r}352,1 \\
18\end{array}$ \\
\hline & Covariance & 9,532 & 2,602 & 9,071 & 5,255 \\
\hline & $\mathrm{N}$ & 68 & 68 & 68 & 68 \\
\hline \multirow[t]{5}{*}{$x 3$} & $\begin{array}{l}\text { Pearson } \\
\text { Correlation }\end{array}$ &, $613^{* *}$ &, $406^{* *}$ & & 1 \\
\hline & Sig. (2-tailed) & ,000 & 001 & ,000 & \\
\hline & $\begin{array}{l}\text { Sum of Squares } \\
\text { and Cross- } \\
\text { products }\end{array}$ & $\begin{array}{r}598,67 \\
6\end{array}$ & $\begin{array}{r}156,8 \\
24\end{array}$ & $\begin{array}{r}352,1 \\
18\end{array}$ & $\begin{array}{r}479,9 \\
41\end{array}$ \\
\hline & Covariance & 8,935 & 2,341 & 5,255 & 7,163 \\
\hline & $\mathrm{N}$ & 68 & 68 & 68 & 68 \\
\hline
\end{tabular}

Hasil pengujian terhadap ada tidaknya korelasi antara variabel $\mathrm{X}_{1}, \mathrm{X}_{2}, \mathrm{X}_{3}$ terhadap $\mathrm{Y}$ tertera pada tabel berikut :

Tabel 4

\section{Correlations}

\begin{tabular}{|ll|r|r|r|r|}
\hline & \multicolumn{1}{|c|}{$\mathrm{Y}$} & $\mathrm{x} 1$ & $\mathrm{x} 2$ & \multicolumn{1}{c|}{$\mathrm{x} 3$} \\
\hline $\mathrm{Y}$ & 1 &, $562^{* *}$ &, $581^{* *}$ &, $613^{* *}$ \\
& Pearson & &, 000 &, 000 \\
& Sig. (2-tailed) & &, 000 &, 000 & \\
Sum of Squares & 1987,2 & 442,0 & 638,6 & 598,6 \\
and Cross- & 21 & 29 & 47 & 76 \\
products & 29,660 & 6,597 & 9,532 & 8,935 \\
Covariance & 68 & 68 & 68 & 68 \\
N &, $562^{* *}$ & 1 &, $401^{* *}$ &, $406^{* *}$ \\
\hline X1 & Pearson & &, 001 &, 001
\end{tabular}

Dari tabel di atas analisis korelasi secara parsial dapat dilihat bahwa :

- korelasi antara variabel terikat Prestasi kerja karyawan (Y) dengan variabel bebas Beban Kerja $\left(X_{1}\right)$ sama dengan 0,562 artinya cukup kuat dan positif searah.

- Korelasi secara parsial antara variabel terikat Prestasi kerja karyawan (Y) dengan variabel bebas Kompetensi $\left(X_{2}\right)$ sama dengan 0,581 artinya cukup kuat dan positif searah.

- Korelasi secara parsial antara variabel terikat Prestasi kerja karyawan (Y) dengan variabel bebas Kompensasi $\left(X_{3}\right)$ sama dengan 0,613 artinya kuat dan positif searah.

Untuk mengetahui tinggi rendahnya pengaruh korelasi menurut Ridwan (2005:138) bahwa klasifikasi tingkat pengaruh yang berlaku untuk arah hubungan adalah sebagai berikut:

Tabel 5

Interpretasi Koefisien Korelasi Nilai $\mathrm{r}$

\begin{tabular}{|c|c|}
\hline Koefisien korelasi & $\begin{array}{c}\text { Tingkat } \\
\text { pengaruh/hubungan }\end{array}$ \\
\hline $0,000-$ & Sangat rendah \\
0,199 & \\
\hline $0,200-$ & Rendah \\
0,399 & \\
\hline $0,400-$ & Cukup kuat \\
0,599 & \\
\hline $0,600-$ & Kuat \\
0,799 & \\
\hline $0,800-$ & Sangat kuat \\
1,000 & \\
\hline
\end{tabular}


Sumber : Ridwan (2005:138)

- Korelasi secara simultan

Tabel 6

Model Summary

\begin{tabular}{|l|c|r|r|r|}
\hline Model & $\mathrm{R}$ & $\begin{array}{c}\mathrm{R} \\
\text { Square }\end{array}$ & $\begin{array}{c}\text { Adjusted R } \\
\text { Square }\end{array}$ & $\begin{array}{c}\text { Std. Error } \\
\text { of the } \\
\text { Estimate }\end{array}$ \\
\hline 1 &, $724^{\mathrm{a}}$ &, 524 &, 502 & 3,845 \\
\hline
\end{tabular}

a. Predictors: (Constant), x3, x1, x2

Sumber : Hasil Pengolahan Data SPSS 22

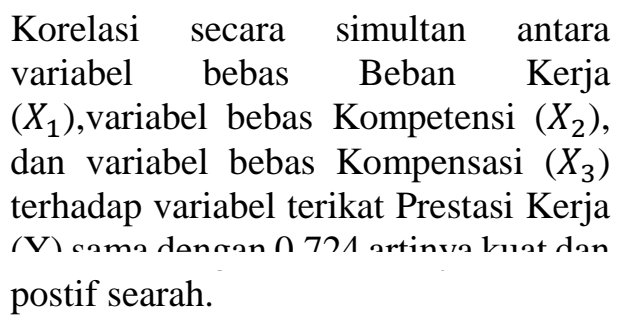

\section{Analisis Determinasi}

\section{Tabel 7}

Model Summary

\begin{tabular}{|l|c|r|r|r|}
\hline Model & $\mathrm{R}$ & $\begin{array}{c}\mathrm{R} \\
\text { Square }\end{array}$ & $\begin{array}{c}\text { Adjusted } \\
\text { R Square }\end{array}$ & $\begin{array}{c}\text { Std. Error } \\
\text { of the } \\
\text { Estimate }\end{array}$ \\
\hline 1 &, $724^{\mathrm{a}}$ &, 524 &, 502 & 3,845 \\
\hline
\end{tabular}

a. Predictors: (Constant), x3, x1, x2

Sumber : Hasil Pengolahan Data SPSS 22

Berdasarkan tabel diatas diperoleh angka $\mathrm{R}$ square sebesar 0,502 atau 50,2\%. Hal ini menunjukan bahwa hubungan variabel independen (beban kerja, kompetensi, dan kompensasi) terhadap variabel dependen (prestasi kerja) sebesar 50,2\%, Sedangkan sisanya sebesar $49,8 \%$ dipengaruhi atau dijelaskan oleh variabel lain yang tidak dimasukkan dalam penelitian ini.

\section{Uji Hipotesis}

$$
\mathbf{U j i}-\mathbf{F}
$$

Pada dasarnya uji $F$ menunjukan seberapa jauh pengaruh satu variabel independen secara parsial dalam menerangkan variabel-variabel dependen.

\section{Tabel 8}

ANOVA $^{\mathrm{a}}$

\begin{tabular}{|l|r|r|r|r|l|}
\hline Model & \multicolumn{1}{|c|}{$\begin{array}{c}\text { Sum of } \\
\text { Squares }\end{array}$} & \multicolumn{1}{c|}{ df } & $\begin{array}{c}\text { Mean } \\
\text { Square }\end{array}$ & F & Sig. \\
\hline $1 \quad$ Regression & 1041,215 & 3 & 347,072 & 23,480 &, $000^{\mathrm{b}}$ \\
Residual & 946,006 & 64 & 14,781 & & \\
$\quad$ Total & 1987,221 & 67 & & & \\
\hline
\end{tabular}

a. Dependent Variable: $y$

b. Predictors: (Constant), x3, x1, x2

Sumber : Hasil Pengolahan Data SPSS 22
Dari tabel diatas dapat dilihat bahwa Fhitung yaitu sebesar 23,480 > Ftabel sebesar 3,14 dengan nilai signifikan yaitu $0,000<0,05$ berarti Ho ditolak Ha diterima ini artinya ada pengaruh signifikan secara simultan dari Beban Kerja, Kompetensi serta Kompensasi terhadap Prestasi Kerja karyawan Hotel Excelton Palembang.

$$
\mathbf{U j i}-\mathbf{T}
$$

Pada dasarnya uji $\mathrm{T}$ menunjukan seberapa jauh pengaruh satu variabel independen secara signifikan dalam menerangkan variasi variabel dependen.

Berikut hasil output SPSS :

\section{Iabel y}

Coefficients $^{\mathrm{a}}$

\begin{tabular}{|c|r|r|r|r|r|}
\hline & \multicolumn{2}{|c|}{$\begin{array}{c}\text { Unstandardized } \\
\text { Coefficients }\end{array}$} & $\begin{array}{c}\text { Standar } \\
\text { dized } \\
\text { Coeffici } \\
\text { ents }\end{array}$ & & \\
\cline { 2 - 4 } Model & \multicolumn{1}{|c|}{ B } & \multicolumn{1}{|c|}{$\begin{array}{c}\text { Std. } \\
\text { Error }\end{array}$} & Beta & \multicolumn{1}{|c|}{ T } & Sig. \\
\hline 1 (Constant) & $-38,016$ & 16,402 & & $-2,318$ &, 024 \\
x1 &, 850 &, 243 &, 336 & 3,496 &, 001 \\
x2 &, 427 &, 210 &, 236 & 2,033 &, 046 \\
x3 &, 657 &, 237 &, 323 & 2,776 &, 007 \\
\hline
\end{tabular}

\section{Sumber : Hasil Pengolahan Data SPSS 22}

Dari tabel diatas dapat dilihat bahwa variabel Beban Kerja dengan nilai signifikan yaitu $0,001<0,05$ berarti Ho ditolak $\mathrm{Ha}$ diterima ini artinya ada pengaruh signifikan secara parsial variabel Beban Kerja terhadap Prestasi Kerja karyawan Hotel Excelton Palembang. Variabel Kompetensi dengan nilai signifikan yaitu $0,046<0,05$ berarti Ho ditolak Ha diterima ini artinya ada pengaruh signifikan secara parsial variabel Kompetensi terhadap Prestasi Kerja karyawan Hotel Excelton Palembang. Variabel Kompensasi dengan nilai signifikan yaitu $0,007<0,05$ berarti Ho ditolak Ha diterima ini artinya ada pengaruh signifikan secara parsial variabel Kompensasi terhadap Prestasi Kerja karyawan Hotel Excelton Palembang. 


\section{KESIMPULAN}

Berdasarkan analisis data dan pengujian hipotesis, maka dapat ditarik kesimpulan sebagai berikut :

1. Secara bersama atau simultan, variabel bebas Beban Kerja, Kompetensi, dan Kompensasi, terdapat pengaruh yang signifikan terhadap variabel terikat Prestasi Kerja Karyawan di Hotel Excelton Palembang. Hal ini dapat dilihat dari besarnya koefisien determinasi yang cukup yaitu $50,8 \%$ yang berarti belum mampu menjelaskan secara optimal pengaruh variabel bebas Beban Kerja $\left(X_{1}\right)$, Kompetensi $\left(X_{2}\right)$, dan Kompensasi $\left(X_{3}\right)$. Jadi masih terdapat $49,8 \%$ yang tidak dapat dijelaskan oleh ketiga variabel bebas tersebut. Masih ada variabel lain yang mempengaruhi selain ketiga variabel tersebut di atas.

2. Secara sendiri-sendiri atau parsial, terdapat pengaruh yang signifikan antara Beban Kerja terhadap Prestasi Kerja Karyawan, Kompetensi terhadap Prestasi Kerja Karyawan dan Kompensasi terhadap Prestasi Kerja Karyawan di Hotel Excelton Palembang.

\section{SARAN}

Sejalan dengan berbagai upaya untuk mengembangkan Prestasi Kerja karyawan di Hotel Excelton Palembang dilihat dari segi Beban Kerja, Kompetensi, dan Kompensasi, maka penulis menyampaikan saran-saran sebagai berikut:

1. Dari hasil pembahasan, Beban Kerja sangat penting bagi Prestasi Kerja karyawan. Oleh karena itu, karyawan hendaknya secara terus menerus meningkatkan kemampuannya, baik kemampuan personal maupun kemampuan manajerial yang kelak akan berimplikasi terhadap perilaku karyawan untuk berprestasi dan berupaya meningkatkan Prestasi Kerja di Hotel Excelton Palembang.

2. Untuk meningkatkan Prestasi Kerja karyawan, perlu diintensifkan kegiatan kompetensi baik secara teknis maupun non teknis. Agar karyawan yang bekerja di Hotel Excelton Palembang dapat meminimalisir tingkat kesalahan dalam bekerja .
3. Di masa yang akan datang, perlu terus menerus diupayakan program Kompensasi di Hotel Excelton Palembang, agar para karyawan di lembaga ini menjadi lebih termotivasi untuk bekerja dengan semangat dan memiliki Prestasi Kerja yang baik.

\section{DAFTAR PUSTAKA}

Anoraga, 2014, Sistem Manajemen Kinerja. Jakarta : Gramedia

Arika, 2011. Budaya Organisasi dan Kinerja. Yogyakarta : Andi Offset

Arikunto, Suharsimi. 2010. Prosedur Penelitian : Suatu Pendekatan Praktik. Edisi Revisi. Jakarta : PT. Rineka Cipta

Ellyzar, Nova, 2017. Evaluasi Kinerja : Penilaian Kinerja Atas Dasar Prestasi Kerja Berorientasi. Yogyakarta: Gajah Mada University Press.

Ghozali, Achmad, 2015, Metodologi Penelitian Kuantitatif, Jakarta : Prenada Media Group

Hanani, Achmad, 2016. Executive Compensation Management, Jakarta : PT. Elekmedia Competindo

Hasibuan, 2010, Sumber Daya Manusia dan Produktivitas Kerja, Bandung : Mandar Maju

Husein, 2013. Memahami Aspek Pengelolaan Sumber Daya Manusia. Yogyakarta : Andi Offset

Martoyo, Nasir. 2010. Metode Penelitian. Jakarta: Ghalia Indonesia.

Munandar, 2014. Telaah Prestasi Kerja Organisasi Publik. Jakarta : Yayasan Obor Indonesia

Muskamal, 2010. Kebijakan Kinerja Karyawan : Kiat Membangun Organisasi Kompetitif Menjelang Perdagangan Bebas Dunia. Jakarta : Gramedia 
Nurma Susilowati, 2019. Pengaruh Beban Kerja, Kompetensi, dan Kompensasi Terhadap Prestasi kerja Karyawan Dengan Motivasi Sebagai Variabel Intervening PT. Bank Syariah Mandiri KCP Kartasura. Surabaya : Jurnal Ilmu Manajemen Universitas Airlangga,Vol.02/Th.III/Maret 2016. Hal.108-119.

Peraturan Menteri Dalam Negeri Nomor 12 Tahun 2008 tentang Pedoman Analisis Beban Kerja Di Lingkungan Departemen Dalam Negeri Dan Pemerintah Daerah

Prayuda, Mahanto, 2014.Pengaruh Kompensasi dan Beban kerja Terhadap Prestasi kerja Karyawan PT. Bank Tabungan Negara (Persero) Tbk, Kantor Wilayah D.I. Yogyakarta, Yogyakarta : Universitas Negeri Yogyakarta, Jurnal Ilmiah Vol.02/Th.III/Maret 2015. Hal.128-139.

Ridwan, 2014, Skala Pengukuran VariabelVariabel Penelitian, Bandung: CV. Alfabeta.

Ryan, T.P., 2010, Modern Regression Methods. New York: John Wiley.
Siagian, Sondang P. 2011. Manajemen Sumber Daya Manusia. Cetakan Kesepuluh. Jakarta: PT Bumi Aksara.

Sugiyono, 2012. Metode Penelitian Kuantitatif, Kualitatif, dan Campuran. Bandung : CV. Alfabeta

Sutrisno, 2011, Manajemen Sumber Daya Manusisa, Jakarta : Penerbit Jambatan.

Sunyoto, 2012. Tinjauan Masalah Prestasi Kerja Karyawan Negeri Sipil di Indonesia. Jakarta : Bumi Aksara

Syarif, Rusli. 2010. Pengambilan Keputusan Strategik untuk Organisasi Publik Non Profit, PT. Grasindo, Yogyakarta

Tarwaka, 2011. Panduan Praktis Penilaian Kinerja Karyawan. Jakarta : PT. Grafindo

Tika, Santiago, 2016, Manajemen Sumber Daya Manusia, Jakarta : Cintya Press 